\title{
PENGARUH KEPEMILIKAN INSTITUSIONAL DAN CORPORATE SOCIAL RESPONSIBILITY TERHADAP PROFITABILITAS PADA PERUSAHAAN PERTAMBANGAN
}

\author{
L. Indrawati ${ }^{1}$, M. Suci ${ }^{2}$, N.D. Andiani ${ }^{3}$ \\ 1,2,3 Jurusan Manajemen, Universitas Pendidikan Ganesha, Singaraja. \\ e-mail: lilyindrawati615@gmail.com, made.suci@undiksha.ac.id, dini.andiani@undiksha.ac.id
}

\begin{abstract}
Abstrak
Penelitian ini bertujuan untuk menguji pengaruh kepemilikan institusional dan CSR terhadap profitabilitas baik secara parsial maupun bersama-sama pada perusahaan pertambangan yang terdaftar di BEI. Desain penelitian ini adalah penelitian kuantitatif kausal. Subjek penelitian adalah perusahaan pertambangan yang terdaftar di BEI dan objeknya adalah kepemilikan institusional, CSR dan profitabilitas. Data dikumpulkan dengan pencatatan dokumen, dan dianalisis dengan analisis regresi linier berganda. Hasil penelitian menunjukkan bahwa kepemilikan institusional dan CSR secara bersama-sama tidak berpengaruh terhadap profitabilitas, kepemilikan institusional berpengaruh positif tetapi tidak signifikan terhadap profitabilitas, CSR berpengaruh positif signifikan terhadap profitabilitas pada perusahaan pertambangan yang terdaftar di BEI.
\end{abstract}

Kata Kunci: kepemilikan institusional, CSR, profitabilitas

\begin{abstract}
This study was aimed to examine the impact of institutional ownership and CSR toward profitability either partial and together mining company profitability that was registered on $B E I$. The design of the study was causal quantitative research. The subject of the study was mining companythat was registered on BEI and its object was institutional ownership, CSR and profitability. The data was collected by document recording and analyzed by multiple linear regression analysis. The result of the study showed that (1) institutional ownership and CSR did not affect the profitability, (2) institutional ownership had positive effect however it did not significantly affect profitability, (3) CSR had significantly positive effect toward mining company profitability registered on BEl.
\end{abstract}

Key words: institutional ownership, CSR, profitability

\section{PENDAHULUAN}

Menghadapi persaingan bisnis yang kompetitif, perusahaan berusaha memperbaiki kinerja dan mengembangkan usaha untuk mencapai tujuan perusahaan yaitu mencapai profit atau laba yang tinggi. Profitabilitas merupakan faktor yang mendapat perhatian penting karena untuk dapat melangsungkan hidup suatu perusahaan harus berada dalam kondisi yang menguntungkan agar investor yang sudah menanamkan modalnya di perusahaan tersebut tidak menarik modalnya kembali dan investor yang belum menanamkan modal pada perusahaan akan tertarik untuk menanamkan modal pada perusahaan yang bersangkutan. Oleh karena itu, perusahaan dituntut untuk memenuhi target yang telah ditetapkan, artinya besarnya laba harus dicapai sesuai dengan target yang sudah ditetapkan. Untuk mengukur tingkat keuntungan suatu perusahaan, digunakan rasio profitabilitas.

Profitabilitas adalah rasio yang digunakan untuk mengukur tingkat efektivitas suatu manajemen perusahaan dalam memperoleh laba (Kasmir, 2008). Rasio Profitabilitas diproksikan dengan ROA. ROA adalah salah satu indikator yang digunakan suatu perusahaan dalam mengukur kinerja suatu perusahaan dan merupakan salah satu rasio profitabilitas yang digunakan untuk mengukur efektifitas perusahaan didalam menghasilkan keuntungan dengan memanfaatkan total aktiva/total asset yang dimiliki (Siamat, 2016). 
Penelitian ini menggunakan ROA sebagai indikator dalam mengukur profitabilitas perusahaan karena ROA lebih komprehensif (menyeluruh) dalam mengukur tingkat pengembalian secara keseluruhan baik dari hutang maupun modal. ROA dapat mengukur kemampuan perusahaan dalam menghasilkan keuntungan operasi dengan total aktiva yang ada.

Salah satu faktor internal yang dapat mempengaruhi profitabilitas suatu perusahaan adalah terjadinya konflik kepentingan antara pemilik dengan pengelola perusahaan. Di Indonesia pengelola perusahaan dinilai belum efektif, karena struktur kepemilikan yang didominasi oleh keluarga, sehingga tidak ada pemisah yang jelas antara kepemilikan dan pengaturan perusahaan, yang menyebabkan manajemen perusahaan cenderung berpihak pada salah satu pemilik saja (Kurniawan dan Indriantoro, 2000). Keadaan seperti inilah yang memicu terjadinya konflik keagenan, sehingga berdampak buruk bagi perusahaan. Pada saat menjalankan tugas, pengelola perusahaan seharusnya memperhatikan kepentingan pemilik, tetapi pada kenyataannya pengelola perusahaan lebih mementingkan kepentingan pribadi, sehingga pengelola sering kali tidak sejalan dengan kepentingan pemilik. Perbedaan kepentingan antara pemilik dan pengelola perusahaan menimbulkan terjadinya masalah yang disebut masalah keagenan.

Konflik keagenan dapat dikurangi dengan adanya kepemilikan institusional yang berperan sebagai pengawas. Kepemilikan institusional memiliki peranan yang penting dalam meminimalisasi konflik keagenan yang terjadi diantara pemegang saham dengan manajer artinya dengan adanya kepemilikan institusional dapat mendorong peningkatan pengawasan yang lebih optimal. Semakin besar persentase yang dimiliki oleh institusi maka pengawasan yang dilakukan lebih efektif sehingga dapat mengendalikan perilaku oportunistik manajer (Jensen and Meckling, 1976).

Penelitian Wiranata dan Nugrahanti (2013), Joesmana (2017) menemukan bahwa, kepemilikan institusional berpengaruh negatif terhadap profitabilitas. Hal tersebut dikarenakan kepemilikan institusional hanya berperan sebagai pengawas yang belum memberikan kontribusi lebih terhadap peningkatan profitabilitas perusahaan (ROA). Berbeda dengan penelitian yang dilakukan oleh Widyati (2013), Rimardhani, dkk (2016), Candradewi dan Sedana (2016) menemukan bahwa kepemilikan institusional berpengaruh positif terhadap ROA karena kepemilikan institusional dapat meningkatkan pengawasan oleh pihak institusi untuk menghalangi tindakan oportunistik manajer.

Selain kinerja perusahaan, secara eksternal lingkungan tempat perusahaan beroprerasi juga mempengaruhi profitabilitas suatu perusahaan. Keadaan lingkungan sekitar tempat bisnis itu berada juga harus diperhatikan terutama yang berdampak langsung maupun tidak langsung dari bisnis yang dijalankan. Saat ini, masyarakat semakin berani untuk mengekspresikan berbagai tuntutannya kepada perusahaan. Isu mengenai peran perusahaan terhadap lingkungan menjadi perhatian bagi masyarakat. Kesadaran masyarakat terhadap dampak perusahaan pada kondisi sosialnya dan lingkungan hidup semakin penting, sehingga mulai menekan perusahaan untuk mengungkapkan pertanggungjawaban sosialnya, karena perusahaan menggunakan sumber daya sebagai penggerak aktivitas. Untuk tetap dapat bertahan perusahaan perlu menunjukkan perannya terhadap lingkungan baik internal (hak dan status karyawan, keselamatan kerja) maupun eksternal (polusi, limbah, penyusutan sumber daya, kualitas, dan keamanan produk) sebagai suatu bentuk tanggung jawab. Dengan memperhatikan keadaan lingkungan sekitar secara tidak langsung akan menaikkan citra perusahaan dibenak masyarakat. Ketika perusahaan memiliki citra yang baik dimata masyarakat, maka akan berpengaruh terhadap profitabilitas perusahaan. Salah satu keuntungan apabila perusahaan menerapkan CSR secara berkelanjutan adalah profitabilitas dan kinerja keuangan yang semakin kuat. Jika CSR diterapkan dalam perusahaan, maka perusahaan akan memperoleh legitimasi sosial dan memaksimalkan kekuatan keuangan dalam jangka panjang (Lako, 2011).

Penelitian Filemon dan Krisnawati (2014), Parengkuan (2017) mengungkapkan bahwa CSR tidak berpengaruh terhadap ROA. Hal tersebut dikarenakan aktivitas 
pengungkapan ataupun pelaksanaan CSR yang dilakukan oleh perusahaan kurang mendapat respon positif baik dari stakeholder maupun shareholder. Berbeda dengan penelitian Husnan dan Pamudji (2013), Putra (2015), Rosdwianti, dkk (2016), Joesmana (2017) yang membuktikan bahwa CSR berpengaruh positif terhadap ROA. Dalam penelitian tersebut menyebutkan bahwa semakin banyak perusahaan melakukan CSR dalam laporan tahunan maka profitabilitas perusahaan akan mengalami peningkatan.

Penelitian ini dilakukan pada Perusahaan Pertambangan yang terdaftar di Bursa Efek Indonesia. Perusahaan pertambangan merupakan perusahaan yang kegiatan operasionalnya bersentuhan lanngsung dengan alam dan lingkungan. Dampak dari kegiatan operasionalnya adalah kerusakan lingkungan sekitar tempat dimana perusahaan tersebut beroperasi. Selain itu, saat ini kegiatan usaha di bidang pertambangan sangat diminati oleh para investor. Dengan demikian perusahaan harus memberikan perhatian khusus terhadap lingkungan yang terkena dampak dari kegiatan operasional tersebut melalui pertanggung jawaban sosial agar lingkungan tetap terjaga serta terjalin hubungan yang baik dengan masyarakat sekitar.

Berdasarkan data pada tahun 2016-2018 pertumbuhan kepemilikan institusional pada perusahaan Atlas Resources Tbk mengalami peningkatan. Pada tahun 20017 mengalami peningkatan sebesar $0,44 \%$ dan pada tahun 2018 mengalami peningkatan sebesar $0,55 \%$. Namun di tahun yang sama profitabilitas perusahaan Atlas Resources Tbk mengalami kerugian. Pada tahun 2017 dalam keadaan rugi profitabilitas meningkat sebesar 2,11\% dan pada tahun 2018 dalam keadaan rugi profitabilitas kembali mengalami penurunan sebesar $3,11 \%$. Hal yang sama terjadi pada perusahaan Bayan Resources Tbk kepemilikan instirusional mengalami fluktuasi. Pada tahun 2017 terjadi peningkatan kepemilikan institusional sebesar 4,04\%, namun pada tahun 2018 kepemilikan institusional mengalami penurunan sebesar $9,83 \%$. Pada tahun yang sama profitabilitas pada perusahaan Bayan Resources Tbk justru mengalami peningkatan yang sangat menonjol. Pada tahun 2017 profitabilitas perusahaan meningkat sebesar $35,8 \%$ dan pada tahun 2018 meningkat sebesar 7,6\%. Begitu juga pada perusahaan Alfa Energi Investama Tbk. Pada tahun 2016-2018 kepemilikan institusional masing-masing meningkat sebesar $0,6 \%$ dan $13,07 \%$. Namun di tahun yang sama profitabilitas perusahaan mengalami penurunan hingga perusahaan dalam keadaan merugi. Pada tahun 2016-2017 profitabilitas perusahaan masing-masing menurun sebesar $1,5 \%$ dan $0,28 \%$.

Hal tersebut tidak sesuai dengan teori yang diungkapkan oleh Jensen \& Meckling (1976) yang menyatakan bahwa semakin besar persentase saham yang dimiliki oleh institusi menyebabkan pengawasan yang dilakukan lebih efektif karena dapat mengendalikan perilaku oportunistik manajer sehingga akan meningkatkan profitabilitas perusahaan melalui kinerja yang baik. Dengan kata lain kepemilikan institusional berpengaruh positif terhadap profitabilitas.

Hal yang sama juga terjadi pada pengungkapan CSR ketiga perusahaan tersebut. Pada tahun 2016-2018 pengungkapan CSR pada perusahaan Atlas Resources Tbk mengalami peningkatan masing-masing $0,033 \%$ dan $0,011 \%$. Hal tersebut diikuti dengan fluktuasi pada profitabilitas perusahaan dalam keadaan rugi. Pada tahun 2017 perusahaan Atlas Resources Tbk mengalami peningkatan sebesar $2,11 \%$ walaupun masih dalam keadaan rugi. Namun pada tahun 2018 profitabilitas perusahaan kembali mengalami penurunan sebesar $3,11 \%$. Hal serupa terjadi pada perusahaan Bayan Resources Tbk. Pada tahun 2016-2017 pengungkapan CSR pada perusahaan Bayan Resources Tbk mengalami peningkatan yang sama masing-masing sebesar $0,11 \%$. Pada tahun yang sama profitabilitas perusahaan meningkat secara drastis yaitu masing-masing sebesar $35,8 \%$ dan 7,6\%. Begitu pula dengan perusahaan Alfa Energi Investama Tbk. Pada tahun 2017 terjadi peningkatan pada pengungkapan CSR sebesar 0,022 dan pada tahun 2018 pengungkapan CSR pada perusahaan Alfa Energi Investama Tbk tidak mengalami perubahan. Namun di tahun yang sama profitabilitas perusahaan mengalami penurunan hingga perusahaan 
dalam keadaan merugi. Pada tahun 2016-2017 profitabilitas perusahaan masing-masing menurun sebesar $1,5 \%$ dan $0,28 \%$.

Berdasarkan fenomena tersebut terjadi kesenjangan teori dengan kenyataan. Hal tersebut tidak sesuai dengan teori yang dikemukakan oleh Lako (2011) yang menyatakan bahwa semakin sering perusahaan mengungkapkan aktivitas sosialnya maka semakin tinggi profitabilitas perusahaan tersebut.

Berdasarkan latar belakang di atas, maka peneliti tertarik untuk melakukan penelitian dengan judul Pengaruh Kepemilikan Institusional dan Corporate Social Responsibility terhadap Profitabilitas pada Perusahaan Pertambangan yang Terdaftar di Bursa Efek Indonesia pada Tahun 2016-2018. Berdasarkan latar belakang masalah penelitian di atas maka rumusan masalah yang dapat diambil yaitu sebagai berikut: (1) Bagaimana pengaruh kepemilikan institusional dan corporate social responsibility terhadap profitabilitas pada perusahaan pertambangan yang terdaftar di Bursa Efek Indonesia? (2) Bagaimana pengaruh kepemilikan institusional terhadap profitabilitas pada perusahaan pertambangan yang terdaftar di Bursa Efek Indonesia? (3) Bagaimana pengaruh corporate social responsibility terhadap profitabilitas pada perusahaan pertambangan yang terdaftar di Bursa Efek Indonesia?

Berdasarkan latar belakang masalah penelitian dan rumusan masalah, adapun tujuan penelitian ini adalah untuk mengetahui hal-hal sebagai berikut: (1) Pengaruh kepemilikan institusional dan corporate social responsibility terhadap profitabilitas pada perusahaan pertambangan yang terdaftar di Bursa Efek Indonesia. (2) Pengaruh kepemilikan institusional terhadap profitabilitas pada perusahaan pertambangan yang terdaftar di Bursa Efek Indonesia. (3) Pengaruh corporate social responsibility terhadap profitabilitas pada perusahaan pertambangan yang terdaftar di Bursa Efek Indonesia.

\section{KAJIAN PUSTAKA DAN PERUMUSAN HIPOTESIS \\ Pengaruh Kepemilikan Institusional terhadap Profitabilitas}

Kepemilikan institusional berpengaruh terhadap profitabilitas. Kepemilikan institusional merupakan proporsi kepemilikan saham institusi lain dalam suatu perusahaan baik institusi pemerintah, swasta, domestik maupun asing yang mengawasi kinerja para manajer perusahaan dalam mengambil keputusan (Joesmana, 2017). Kepemilikan saham institusional berpengaruh positif menunjukkan bahwa fungsi kontrol dari pemilik sangat menentukan dalam meningkatkan kinerja perusahaan. Secara teoritis bahwa semakin tinggi kepemilikan institusional, maka semakin kuat kontrol terhadap perusahaan dan kinerja perusahaan akan naik apabila pemilik perusahaan bisa mengendalikan perilaku manajemen agar bertindak sesuai dengan tujuan perusahaan (Darwis, 2009).

Penelitian Wiranata dan Nugrahanti (2013), Joesmana (2017) menemukan bahwa, kepemilikan institusional berpengaruh negatif terhadap profitabilitas. Hal tersebut dikarenakan kepemilikan institusional hanya berperan sebagai pengawas yang belum memberikan kontribusi lebih terhadap peningkatan profitabilitas perusahaan (ROA). Berbeda dengan penelitian yang dilakukan oleh Widyati (2013), Rimardhani, dkk (2016), Candradewi dan Sedana (2016) menemukan bahwa kepemilikan institusional berpengaruh positif terhadap ROA karena kepemilikan institusional dapat meningkatkan pengawasan oleh pihak institusi untuk menghalangi tindakan oportunistik manajer.

$\mathrm{H}_{1}$ : Terdapat pengaruh kepemilik-an institusional terhadap profitabilitas pada perusahaan pertambangan yang terdaftar di Bursa Efek Indonesia.

\section{Pengaruh Corporate Social Responsibility terhadap Profitabilitas}

Corporate Social Responsibility merupakan suatu tindakan atau konsep yang dilakukan oleh perusahaan sebagai bentuk tanggung jawab mereka terhadap sosial atau lingkungan sekitar dimana perusahaan itu berada. Corporate Social Responsibility merupakan mekanisme bagi suatu perusahaan untuk secara sukarela mengintegrasikan perhatian terhadap lingkungan dan sosial ke dalam kegiatan operasinya dan interaksinya 
dengan para pemangku kepentingan lainnya (stakeholder) yang melebihi tanggung jawab organisasi di bidang hukum (Parengkuan, 2017).

Semakin sering perusahaan mengungkapkan aktivitas sosialnya maka investor akan semakin tertarik dengan perusahaan tersebut dan perusahaan akan memperoleh kepercayaan dimata investor. Hal tersebut juga akan memberikan citra baik dimata masyarakat dan akan memaksimalkan kekuatan keuangan dalam jangka panjang.

Penelitian Filemon dan Krisnawati (2014), Parengkuan (2017) mengungkapkan bahwa CSR tidak berpengaruh terhadap ROA. Hal tersebut dikarenakan aktivitas pengungkapan ataupun pelaksanaan CSR yang dilakukan oleh perusahaan kurang mendapat respon positif baik dari stakeholder maupun shareholder. Berbeda dengan penelitian Husnan dan Pamudji (2013), Putra (2015), Rosdwianti, dkk (2016), Joesmana (2017) yang membuktikan bahwa CSR berpengaruh positif terhadap ROA. Dalam penelitian tersebut menyebutkan bahwa semakin banyak perusahaan melakukan CSR dalam laporan tahunan maka profitabilitas perusahaan akan mengalami peningkatan.

$\mathrm{H}_{2}$ : Terdapat pengaruh corporate social responsibility terhadap profitabilitas pada perusahaan pertambangan yang terdaftar di Bursa Efek Indonesia.

\section{METODE}

Penelitian ini menggunakan rancangan penelitian kuantitatif kausal. Kuantitatif kausal merupakan penelitian pendekatan ilmiah terhadap pengambilan keputusan manajerial ekonomi yang bertujuan untuk mendapatkan bukti hubungan sebab akibat atau pengaruh dari variabel - variabel penelitian. Penelitian ini dilakukan untuk mengetahui pengaruh kepemilikan institusional dan corporate social responsibility terhadap profitabilitas pada perusahaan pertambangan yang terdaftar di Bursa Efek Indonesia Tahun 2016 - 2018.

Variabel dalam penelitian ini adalah kepemilikan institusional $\left(X_{1}\right)$ dan CSR $\left(X_{2}\right)$ sedangkan variabel terikat adalah profitabilitas $(\mathrm{Y})$.

Subjek dalam penelitian ini adalah perusahaan pertambangan yang terdaftar di Bursa Efek Indonesia Tahun 2016 - 2018. Sedangkan untuk objeknya adalah kepemilikan institusional $\left(\mathrm{X}_{1}\right)$ dan CSR $\left(\mathrm{X}_{2}\right)$ sedangkan variabel terikat adalah profitabilitas $(\mathrm{Y})$. Populasi yang digunakan dalam penelitian ini adalah Perusahaan Pertambangan yang terdaftar di Bursa Efek Indonesia periode 2016-2018 dengan jumlah populasi sebanyak 25 perusahaan.

Penelitian ini merupakan penelitian populasi yang dilakukan pada perusahaan pertambangan yang terdaftar di Bursa Efek Indonesia dan perusahaan pertambangan yang menyertakan laporan keuangan pada periode 2016-2018. Perusahaan pertambangan yang terdaftar di Bursa Efek Indonesia berjumlah 25 perusahaan, akan tetapi terdapat 15 perusahan yang tidak menyertakan laporan keuangan pada periode 2016-2018, sehingga sampel yang digunakan dalam penelitian ini berjumlah 10 perusahaan yang menyertakan laporan keuangan pada periode 2016-2018.

Jenis data yang digunakan dalam penelitian ini adalah data kuantitatif berupa data sekunder. Sumber data dalam penelitian ini adalah data sekunder, yang diperoleh dari laporan keuangan yang dipublikasikan perusahaan pertambangan yang terdaftar di Bursa Efek Indonesia periode 2016-2018 di www.idx.co.id. Teknik analisis data yang digunakan adalah analisis regresi linier berganda. Data yang akan dianalisis dalam penelitian ini berkaitan dengan hubungan antar variabel-variabel. Analisis data dilakukan secara kuantitatif dengan tahapan yaitu: (1) uji asumsi klasik, (2) analisis regresi linear berganda dan (3) koefisien determinasi. Tujuannya adalah menetapkan apakah variabel bebas mempunyai hubungan dengan variabel terikatnya, penetapan tingkat signifikasi, dan diakhiri dengan penelitian dasar penarikan kesimpulan melalui penerimaan atau penolakan hipotesis.

\section{HASIL DAN PEMBAHASAN Hasil}

Adapun hasil pengujian hipotesis dengan analisis regresi linier berganda pada 
pengaruh kepemilikan institusional dan CSR terhadap profitabilitas pada perusahaan pertambangan yang terdaftar di Bursa Efek Indonesia sebagai berikut.

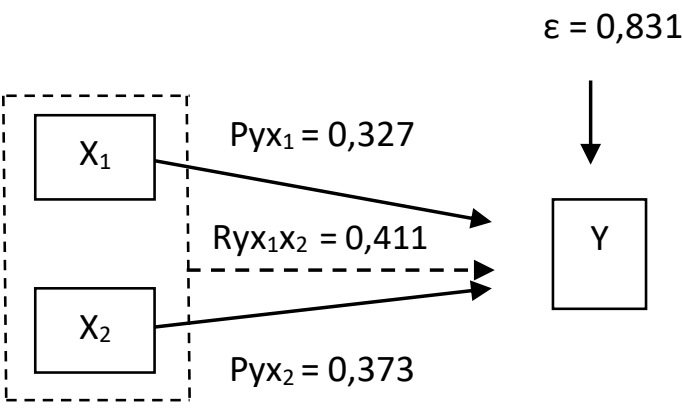

Gambar 1

Struktur Pengaruh Variabel Kepemilikan Institusional $\left(\mathrm{X}_{1}\right)$ dan CSR $\left(\mathrm{X}_{2}\right)$ terhadap

Profitabilitas $(Y)$ 
Hipotesis penelitian pertama "Ada pengaruh simultan dari Kepemilikan Institusionaldan CSR terhadap ROA". Berdasarkan rekapan hasil uji regresi berganda menunjukan hasil Ryx1x2 =0,411 dengan $p$-value $0,082>0,05$, yang menyatakan bahwa menerima Ho yang berarti tidak ada pengaruh signifikan dari Kepemilikan Institusional (X1) dan CSR (X2) terhadap ROA $(Y)$, dilihat dari sumbangan pengaruh hanya sebesar $16,9 \%$. Hasil tersebut menunjukan bahwa hanya sebesar 16,9\% ROA (Y) dipengaruhi oleh Kepemilikan Institusional (X1) dan CSR (X2). Sedangkan pengaruh variabel lain di luar Kepemilikan Institusional (X1) dan CSR (X2) adalah sebesar 83,1\%. Hal ini dapat disimpukan bahwa variabel Kepemilikan Institusional (X1) dan CSR (X2) secara bersamasama tidak secara signifikan berperan dalam meningkatkan ROA $(Y)$. Sehingga hipotesis pertama penelitian ini ditolak.

Hipotesis penelitian kedua "Ada pengaruh parsial dari Kepemilikan Institusional terhadap ROA". Berdasarkan rekapan hasil uji regresi berganda menunjukan hasil Pyx1 = 0,327 dengan $p$-value $0,084>0,05$, nilai signifikansi ini lebih besar dari pada probabilitas 0,05, maka HO diterima. Sehingga dapat disimpulkan bahwa variabel kepemilikan institusional (X1) tidak memiliki kontribusi terhadap profitabilitas yang diproksikan dengan (Y). Nilai t positif menunjukkan bahwa variabel kepemilikan institusional (X1) mempunyai hubungan yang searah dengan profitabilitas $(Y)$. Jadi dapat disimpulkan variabel kepemilikan institusional (X1) memiliki pengaruh positif tetapi tidak signifikan terhadap profitabilitas $(Y)$ yang diproksikan dengan ROA. Sehingga hipotesis kedua dalam penelitian ini ditolak.

Hipotesis penelitian ketiga "Ada pengaruh parsial dari CSR terhadap ROA". Berdasarkan rekapan hasil uji regresi berganda menunjukan hasil Pyx2 $=0,373$ dengan $p$ value $0,046<0,05$, yang menyatakan bahwa menolak Ho yang berarti ada pengaruh positif dan signifikan dari CSR (X2) terhadap ROA (Y), dengan sumbangan pengaruh sebesar 13,9\%. Hal ini dapat disimpukan bahwa variabel CSR secara parsial berperan dalam meningkatkan ROA. Sehingga hipotesis ketiga penelitian ini diterima.

\section{Pembahasan}

Kepemilikan institusional dan CSR tidak secara signifikan berperan dalam meningkatkan profitabilitas yang diproksikan dengan ROA. Hal ini diakibatkan karena ROA merupakan perbandingan antara laba bersih setelah pajak dengan total aktiva untuk mengukur tingkat pengembalian investasi (Parengkuan, 2017), sedangkan kepemilikan institusional hanya memiliki peran penting dalam meminimalisir konflik keagenan yang terjadi antara pemilik perusahaan dan manajer (Jensen \& Meckling, 1976) dan CSR merupakan mekanisme bagi suatu perusahaan untuk secara sukarela mengintegrasikan perhatian terhadap lingkungan dan sosial ke dalam kegiatan operasinya dan interaksinya dengan para pemangku kepentingan lainnya (stakeholder) yang melebihi tanggung jawab organisasi di bidang hukum (Parengkuan, 2017). Hal tersebut didukung oleh penelitian dari Hermayanti \& Sukartha (2019) yang mengatakan bahwa kepemilikan institusional dan CSR secara bersama-sama tidak berpengaruh dalam meningkatkan profitabilitas yang diproksikan dengan ROA.

Pada hasil pengujian antara kepemilikan institusional terhadap profitabilitas yang diproksikan dengan ROA, kepemilikan institusional berpengaruh positif tetapi tidak signifikan dalam meningkatkan ROA. Kepemilikan institusional merupakan proporsi kepemilikan saham institusi lain dalam suatu perusahaan baik institusi pemerintah, swasta, domestik maupun asing yang mengawasi kinerja para manajer perusahaan dalam mengambil keputusan. Hasil penelitian tidak sesuai dengan teori Jensen \& Meckling (1976) yang menyatakan bahwa semakin tinggi kepemilikan institusional, maka semakin kuat kontrol terhadap perusahaan dan kinerja perusahaan akan naik apabila pemilik perusahaan bisa mengendalikan perilaku manajemen agar bertindak sesuai dengan tujuan perusahaan. Jika dilihat dari data penelitian pada perusahaan pertambangan, tidak semua perusahaan dimiliki 
oleh institusi atau dengan kata lain persentase kepemilikan oleh institusi rendah. Rendahnya persentase kepemilikan institusional menyebabkan proses monitoring terhadap manajer tidak efektif sehingga tidak mempengaruhi kinerja perusahaan. Dari penjelasan tersebut besarnya persentase kepemilikan institusional dapat memberikan pengawasan yang lebih optimal terhadap kinerja manajemen perusahaan dalam mengambil keputusan. Sehingga jika persentase kepemilikan institusional tidak terlalu besar, hal tersebut tidak akan memberikan pengawasan yang optimal terhadap manajemen perusahaan. Hasil penelitian ini sejalan dengan penelitian yang dilakukan oleh Wiranata \& Nugrahanti (2013) dan Joesmana (2017) yang menemukan bahwa kepemilikan institusional tidak berpengaruh terhadap ROA.

CSR berpengaruh positif dan signifikan terhadap profitabilitas yang diproksikan dengan ROA. Hal ini sejalan dengan penelitian yang dilakukan Husnan dan Pamudji (2013), Putra (2015), Rosdwianti, dkk (2016), Joesmana (2017) yang membuktikan bahwa CSR berpengaruh positif terhadap ROA. Dalam penelitian tersebut menyebutkan bahwa semakin banyak perusahaan melakukan CSR dalam laporan tahunan maka profitabilitas perusahaan akan mengalami peningkatan.

CSR merupakan mekanisme bagi suatu perusahaan untuk secara sukarela mengintegrasikan perhatian terhadap lingkungan dan sosial ke dalam kegiatan operasinya dan interaksinya dengan para pemangku kepentingan lainnya (stakeholder) yang melebihi tanggung jawab organisasi di bidang hukum. Jika CSR diterapkan dalam perusahaan, maka perusahaan akan memperoleh legitimasi sosial dan memaksimalkan kekuatan keuangan dalam jangka panjang (Lako, 2011). Semakin sering perusahaan mengungkapkan aktivitas sosialnya maka investor akan semakin tertarik dengan perusahaan tersebut dan perusahaan akan memperoleh kepercayaan dimata investor. Hal tersebut juga akan memberikan citra baik dimata masyarakat dan akan meningkatkan loyalitas konsumen. Seiring meningkatnya loyalitas konsumen maka penjualan perusahaan akan meningkat dan diharapkan profitabilitas perusahaan juga meningkat.

Berdasarkan data penelitian tersebut perusahaan sudah melakukan kegiatankegiatan yang disesuaikan dengan keadaan lingkungan sekitarnya, baik dalam hal pelestarian lingkungan tempat perusahaan itu beroperasi maupun tentang kesejahteraan masyarakat melalui pemberdayaan ataupun pendidikan ketenagakerjaan. Melalui CSR perusahaan diharapkan mampu mencapai tujuan utama perusahaan yaitu mencari laba tanpa mengabaikan kepentingan stakeholder dan kelestarian lingkungan sebagai bentuk tanggung jawab atas dampak yang telah ditimbulkan akibat kegiatan operasional perusahaan.

\section{SIMPULAN DAN SARAN Simpulan}

Berdasarkan hasil pembahasan yang telah dilakukan dapat ditarik simpulan sebagai berikut: (1) Kepemilikan institusional dan CSR secara bersama-sama tidak berpengaruh terhadap profitabilitas pada perusahaan pertambangan yang terdaftar di Bursa Efek Indonesia. (2) Kepemilikan institusional berpengaruh positif tetapi tidak signifikan terhadap profitabilitas pada perusahaan pertambangan yang terdaftar di Bursa Efek Indonesia. (3) CSR berpengaruh positif dan signifikan terhadap profitabilitas pada perusahaan pertambangan yang terdaftar di Bursa Efek Indonesia.

\section{Saran}

Berdasarkan simpulan yang telah dikemukakan, maka saran yang dapat dianjurkan sebagai berikut: (1) Bagi perusahaan pertambangan diharapkan mampu meningkatkan persentase kepemilikan oleh institusi lain melalui pengoptimalan laba perusahaan yang dapat dilakukan dengan pemanfaatan sumber daya yang dimilikinya. Pihak perusahaan pertambangan dapat mengoptimalkan pengawasan terhadap kinerja keuangan perusahaan agar dapat memberikan keuntungan bagi semua pihak yang berkepentingan. Selain itu perusahaan juga harus memperhatikan lingkungan sosialnya melalui kegiatan CSR. 
Semakin perusahaan sering mengungkapkan kegiatan sosialnya maka citra perusahaan akan baik dan tentunya akan berdampak pada peningkatan profitabilitas perusahaan. Serta kegiatan CSR juga hendak di sesuaikan dengan kondisi masyarakat sekitar. (2) Bagi peneliti selanjutnya diharapkan dapat melakukan penelitian lebih lanjut mengenai profitabiitas serta dapat menambahkan variabel-variabel lainnya. Peneliti ini meneliti perusahaan pertambangan yang terdaftar di BEI, untuk peneliti selanjutnya diharapkan dapat melakukan penelitian pada perusahaan sub sektor lainnya yang terdaftar di BEl. Peneliti selanjutnya juga dapat menambahkan periode penelitian agar lebih mudah melihat perkembangan profitabilitas.

\section{DAFTAR PUSTAKA}

Brigham, E.F. dan Houston, J.F. 2006. Dasar-dasar Manajemen Keuangan Buku 1. Jakarta: Salemba Empat.

Candradewi, Intan, Sedana, Ida Bagus Panji, (2016), "Pengaruh Kepemilikan Manajerial, Kepemilikan Institusional, dan Dewan Komisaris Independen Terhadap Return On Asset," E-Jurnal Manajemen Unud, Vol. 5, No. 5, 2016: 3163-3190.

Darwis, Herman. 2009. Corporate Governance Terhadap Kinerja Perusahaan. Jurnal Keuangan dan Perbankan, Vol. 13, No.3, September 2009, hal. 418-430.Brigham dan Houston. 2010. Dasar-dasar Manajemen Keuangan Buku 1\& 2 (Edisi 11): Salemba Empat Jakarta.

Deegan. C, Rankin. M, Tobin. J. 2002. "An Examination of the Corporate Social and Environmental Disclosure BHP from 1983-1997 a Test of Legitimacy Theory". Accounting, Auditing and Acountability. Vol. 15, No 3, pp 312343.

Dowling, J. and Pfeffer, J. 1975. "Organizational Legitimacy: Social Values and Organizational Behaviour". Pacific Sociological Review. Vol. 18. pp. 122-136.

Fama, Eugene F. dan Jensen, M.C. 1983. Separation Of Ownership and Control. Journal Of Law and Economics, Vol. XXVI, Juni, hal. 301-326.

Filemon, Christian Noel, Krisnawati, Astrie, (2014), "Pengaruh Corporate Social Responsibility Disclosure terhadap Return On Assets Pada Perusahaan Telekomunikasi yang Terdaftar di Bursa Efek Indonesia," Jurnal Manajemen Indonesia, Vol. 14, No. 3, Desember 2014

Gray, R.H. Owen, D. and Adam, C. 1996. Accounting and Accountability, Hemel Hempstead: Prentics Hall.

Gujarati, Damodar N. 2004. Dasar-dasar Ekonometrika Jilid I Edisi Ketiga. Jakarta: Erlangga.

Husnan, Ahmad, Pamudji, Sugeng, (2013), "Pengaruh Corporate Social Responsibility (CSR DISCLOSURE) terhadap Kinerja Keuangan Perusahaan," Journal Of Accounting, Vol. 2, No. 2, 2013: 2337-3806.

Jensen, M.C dan W.H. Meckling. 1976. Theory of The Firm: Managerial Behavior, Agency Cost And Ownership Structure. Journal of Financial Economics 3: 305-360.

Joesmana, Windy Amadhea, (2017), "Pengaruh Corporate Social Responsibility (CSR) terhadap Kinerja Keuangan (Studi Pada Sektor Pertambangan yang Terdaftar di BEI 2013-2015)," Jurnal Akuntansi Keuangan.

Kasmir. 2015. Manajemen Perbankan. Jakarta: PT Raja Grafindo Persada.

Kurniawan, Dudi dan Nur Indriantoro. 2000. Corporate Governance in Indonesia. The Second Asian Roundtable on Corporate Governance.

Lako, Andreas. 2011. Dekonstruksi CSR dan Reformasi Paradigma Bisnis dan Akuntansi. Jakarta: Erlangga.

Nor, Hadi. 2011. Corporate Social Responsibility. Yogyakarta: Graha IImu.

Parengkuan, Winnie Eveline, (2017), "Pengaruh Corporate Social Responsibility (CSR) terhadap Kinerja Keuangan Perusahaan Manufaktur yang Terdaftar di Bursa Efek Indonesia," Jurnal EMBA, Vol. 5, No. 2, Juni 2017. 
Putra, Anggara Satria, (2015), "Pengaruh Corporate Social Responsibility terhadap Profitabilitas Perusahaan (Studi Empiris pada Perusahaan Sektor Industri Barang Konsumsi yang Terdaftar di Bursa Efek Indonesia Tahun 2010-2013)," Jurnal Nominal, Vol. IV, No. 2.

Rimardhani, Helfina, dkk, (2016), "Pengaruh Mekanisme Good Corporate Governance terhadap Profitabilitas Perusahaan (Studi Pada Perusahaan BUMN yang Terdaftar di BEI Tahun 2012-2014)," Jurnal Administrasi Bisnis, Vol. 31, No. 1, Februari 2016.

Rosdwianti, Mega Karunia, dkk, (2016), "Pengaruh Corporate Social Responsibility terhadap Profitabilitas Perusahaan (Studi Pada Sektor Industri Barang Konsumsi yang Terdaftar di Bursa Efek Indonesia Tahun 2013-2014)," Jurnal Administrasi Bisnis, Vol. 38, No. 2, September 2016.

Siamat, Dahlan, 2004. Manajemen Lembaga Keuangan. Edisi Keempat. Jakarta: Fakultas Ekonomi Universitas Indonesia.

Sugiyono. 2009. Metode Penelitian Pendidikan. Bandung: PT Alfabeta. 2010. Metode Penelitian Kuantitatif,Kualitatif dan $R \& D$. Bandung: PT Alfabeta.

Widyati, Maria Fransisca, (2013), "Pengaruh Dewan Direksi, Komisaris Independen, Komite Audit, Kepemilikan Manajerial dan Kepemilikan Institusional terhadap Kinerja Keuangan," Jurnal IImu Manajemen, Vol. 1, No. 1, Januari 2013.

Wiranata, Yulius Ardy, Nugrahanti, Yeterina Widi, (2013), "Pengaruh Dewan Direksi, Komisaris Independen, Komite Audit, Kepemilikan Manajerial dan Kepemilikan Institusional terhadap Kinerja Keuangan," Jurnal Akuntansi dan Keuangan, Vol. 15, No. 1, Mei 2013: 2338-8137 